\title{
Wave action limits crowding in an intertidal mussel
}

\author{
Jorge L. Gutiérrez ${ }^{1,2,3, *}$, M. Gabriela Palomo ${ }^{1,4}$, María Bagur ${ }^{4}$, Lorena P. Arribas ${ }^{4}$, \\ Sabrina A. Soria ${ }^{4}$ \\ ${ }^{1}$ Grupo de Investigación y Educación en Temas Ambientales (GrIETA), San Eduardo del Mar, Argentina \\ ${ }^{2}$ Facultad de Ciencias Exactas y Naturales and CONICET, Universidad Nacional de Mar del Plata, Mar del Plata, Argentina \\ ${ }^{3}$ Cary Institute of Ecosystem Studies, Millbrook, NY 12545, USA \\ ${ }^{4}$ Museo Argentino de Ciencias Naturales ‘Bernardino Rivadavia' (MACN-CONICET), Buenos Aires, Argentina
}

\begin{abstract}
Intraspecific competition for space is generally invoked as the chief process limiting crowding in sessile or highly sedentary marine invertebrates. However, the mechanisms by which high conspecific density induces individual removal or mortality, in turn restraining crowding in these organisms, generally remain uninvestigated. Here we illustrate that mussel crowding in a southwestern Atlantic rocky intertidal shore is limited by a combination of wave action and space limitation. Brachidontes rodriguezii mussel beds at this site occur primarily as a single layer of individuals because wave forces remove multilayered mussel hummocks quickly after they develop. Mussels in hummocks show lower attachment strength than those in the single-layered matrix. Accordingly, wave conditions associated with the passage of cold fronts (i.e. transition zones from warm air to cold air accompanied by moderate to strong winds and wave action, with $7 \mathrm{~d}$ average recurrence times based on historical weather data) cause detectable mussel dislodgment in a high proportion of hummocks but have virtually no impact on single-layered areas. Since wave action is the proximate cause of mussel dislodgment, upper limits to crowding in this species would not be fixed to a particular level of space occupation (i.e. as predictable from interindividual interference alone) but would be variable in space and time depending on wave exposure. This example suggests a mechanism of population control where the impact of a physical factor on population size is larger at higher population density and supports early hypotheses about the occurrence of density-dependent population control by physical factors when the availability of safe sites is limiting.
\end{abstract}

KEY WORDS: Density dependence - Dislodgment - Intraspecific competition - Hummocking • Multilayering $\cdot$ Physical factors $\cdot$ Rocky shore $\cdot$ Space limitation

\section{INTRODUCTION}

Aggregation with conspecifics is widespread in animals. Benefits from aggregation include increased opportunity for reproduction, higher foraging efficiency, and protection from predators and adverse environmental conditions (Allee 1927, Krause \& Ruxton 2002). In gregarious marine invertebrates with sessile or highly sedentary adult stages, aggre- gation with conspecifics generally occurs at the time of larval settlement and in response to physical or chemical cues from adults or the adult habitat (Burke 1986, Pawlik 1992; but see Nicastro et al. 2008, van de Koppel et al. 2008). Positive responses of settling larvae to adults, however, do not lead to unlimited increases in adult population densities. Even when the larval supply is not limiting, there is clearly a maximum level of crowding at which individuals can 
occur. These limits to crowding have become evident from self-thinning relationships (i.e. negative relationships between individuals per area and average individual mass or biomass per area; see Westoby 1984, Fréchette \& Lefaivre 1995) found for a variety of sessile or highly sedentary marine invertebrates (see Hogarth 1985, Hughes \& Griffiths 1988, Guiñez \& Castilla 1999, 2001). Intraspecific competition for space (i.e. organismal mortality or removal due to increased inter-individual interference as space becomes scarce) is generally invoked as the main factor limiting crowding and leading to self-thinning relationships in these organisms. In virtually all cases, however, it remains unexplained how high conspecific density induces individual mortality or removal and, in turn, restrains crowding.

Mussels frequently form extensive beds in rocky intertidal shores. Depending on mussel species and habitats, these beds can range from a single layer of individuals attaching to the rock substrate, to multiple layers where mussels in the top layers attach to conspecifics (up to 4 layers in Mytilus galloprovincialis; 6 layers in $M$. californianus, and 5 layers in Brachidontes purpuratus; Hosomi 1985, Suchanek 1986, Guiñez et al. 2005; see Guiñez 2005 for a review). The factors limiting the accrual of multiple mussel layers in single-layered beds have not yet been evaluated. However, several authors have documented the occurrence of isolated multi-layered patches - or hummocks - interspersed within primarily single-layered mussel beds (e.g. Seed 1976, Hunt \& Scheibling 1995, Davenport et al. 1998). Hummocks apparently develop as densely-aggregated mussels grow and have been proposed as particularly susceptible to wave disturbance (see Seed 1976, Hunt \& Scheibling 1995, Davenport et al. 1998, Carrington 2002a). Mussel attachment to conspecifics - which likely prevails in hummocks - was found to be weaker than their attachment to rock (Harger \& Landenberger 1971). Based on these observations, here we hypothesized that wave action limits mussel crowding to a single layer of individuals by dislodging weakly-attached, hummocked mussels rapidly after hummocks form.

We evaluated the above hypothesis in Southwestern Atlantic intertidal beds of $B$. rodriguezii. This relatively small mytilid (up to $55 \mathrm{~mm}$ length, most individuals less than $30 \mathrm{~mm}$ length) occurs at high densities (up to 200000 ind. $\mathrm{m}^{-2}$ ) and dominates the mid-intertidal zone of Argentinean rocky shores located north of San Matías Gulf $\left(41^{\circ}\right.$ S; Penchaszadeh 1973, Arribas et al. 2013, Trovant et al. 2013). It forms primarily single-layered beds in horizontal or nearly-horizontal rock surfaces (although multi-layering often occurs on the sides of boulders or other vertical or nearly vertical intertidal substrates; Penchaszadeh 1973, authors' pers. obs.). Hummocks (5 to $70 \mathrm{~cm}^{2}$ area, oval contour) were observed at relatively low densities in horizontal, primarily single-layered beds of $B$. rodriguezii and those of a morphologically similar species, B. purpuratus (formerly Perumytilus purpuratus), across several intertidal locations of coastal Argentina (Table 1). To evaluate our hypothesis, we first characterized hummocks and single-layered areas of $B$. rodriguezii beds in terms of mussel numbers and size, and identified thresholds in mussel abundance, biomass, and volume per area unit above which hummocks develop. Secondly, we compared attachment strength between mussels occurring in hummocks and single-layered areas and evaluated whether hummocks are more prone to be disturbed by waves than single-layered areas of the mussel bed. Last, we assessed the probabilities of transition from hummocked to single-layered mussel bed areas and vice versa and estimated the long-run proportion of time at which each of these statuses occur.

Table 1. Records of mussel hummocking in beds of Brachidontes rodriguezii (BR) and B. purpuratus (BP) across southwestern Atlantic rocky intertidal locations. Mean (SD) density of hummocks (obtained from 3 transects $10 \mathrm{~m}$ long $\times$ $1 \mathrm{~m}$ wide) and mean (SD) hummock sizes (estimated as the area covered by an ellipse after measurement of its major and minor diameter) are reported. All sites were sampled between 10 March and 6 April 2013. Note that the list is illustrative, not exhaustive (i.e. hummocks are likely to occur at locations other than those shown here). NA: data not available

\begin{tabular}{|c|c|c|c|c|}
\hline \multirow[t]{2}{*}{ Location (Species) } & \multicolumn{2}{|c|}{ Coordinates } & \multirow{2}{*}{$\begin{array}{c}\text { Density } \\
\text { (hummocks m}^{-2} \text { ) }\end{array}$} & \multirow[t]{2}{*}{ Size $\left(\mathrm{cm}^{2}\right)$} \\
\hline & & W & & \\
\hline Santa Elena (BR) & $37^{\circ} 86^{\prime}$ & $57^{\circ} 51^{\prime}$ & $0.87(0.12)$ & $15.08(5.98)$ \\
\hline Punta Cantera (BR) & $38^{\circ} 05^{\prime}$ & $57^{\circ} 32^{\prime}$ & $0.67(0.12)$ & 31.51 (11.39) \\
\hline Miramar (BR) & $38^{\circ} 17^{\prime}$ & $57^{\circ} 50^{\prime}$ & $2.23(1.27)$ & $9.33(4.76)$ \\
\hline El Espigón (BR) ${ }^{\mathrm{a}}$ & $41^{\circ} 07^{\prime}$ & $63^{\circ} 00^{\prime}$ & $3.47(1.91)$ & $24.08(10.20)$ \\
\hline La Lobería $(\mathrm{BR})^{\mathrm{a}}$ & $41^{\circ} 09^{\prime}$ & $63^{\circ} 07^{\prime}$ & $1.57(0.35)$ & $12.05(4.90)$ \\
\hline Playas Doradas (BP) & $41^{\circ} 38^{\prime}$ & $65^{\circ} 01^{\prime}$ & NA & $13.06(4.06)$ \\
\hline Puerto Lobos $(\mathrm{BP} ; \mathrm{BR})^{\mathrm{b}}$ & $41^{\circ} 59^{\prime}$ & $65^{\circ} 04^{\prime}$ & $2.86(0.68)$ & $40.68(14.46)$ \\
\hline Punta Cuevas (BP; BR) ${ }^{\mathrm{b}}$ & $42^{\circ} 46^{\prime}$ & $65^{\circ} 00^{\prime}$ & $2.33(0.60)$ & $45.52(10.16)$ \\
\hline \multicolumn{5}{|c|}{$\begin{array}{l}{ }^{a} B \text {. purpuratus occurs in low numbers at these locations (Arribas et al. 2013) } \\
\text { both species co-occur at the regional scale (see Trovant et al. 2013), but } \\
\text { species determinations were not made here to confirm co-occurrence at } \\
\text { these locales }\end{array}$} \\
\hline
\end{tabular}




\section{MATERIALS AND METHODS}

\section{Study sites}

This study was primarily conducted at Punta Cantera (Mar del Plata, Buenos Aires Province, Argentina; $38^{\circ} 05^{\prime} \mathrm{S}, 57^{\circ} 32^{\prime} \mathrm{W}$ ). This area is characterized by low-amplitude tides (mean: $0.80 \mathrm{~m}$ ) and a gentle slope, which allows the development of extensive Brachidontes rodriguezii beds. The rock substrate is orthoquartzite and occurs both in the form of boulders (up to $4 \mathrm{~m}$ maximum length) and continuous platforms interspersed by channels and tidal pools (Jaubet \& Genzano 2011). For comparative purposes, additional measurements of mussel attachment strength were carried out in intertidal limestone platforms at El Espigón (15 km W of Balneario El Cóndor, Río Negro Province, Argentina; $41^{\circ} 07^{\prime} \mathrm{S}, 63^{\circ} 00^{\prime} \mathrm{W}$ ). This is a macrotidal area (ca. $4 \mathrm{~m}$ mean tidal amplitude) also characterized by extensive $B$. rodriguezii beds (Arribas et al. 2013). All sampling and measurements were carried out on horizontal rock surfaces located at the mid-intertidal zone.

\section{Characterization of mussel hummocks}

Hummocks, single-layered areas immediately adjacent to hummocks, and single-layered areas $30 \mathrm{~cm}$ away from them were compared with regard to mussel abundance, biomass, and volume per area unit. Mussel samples $(5 \times 5 \mathrm{~cm}$ squares) were taken from each of these places on 08 December 2011 and 30 April 2012 ( $\mathrm{n}=7$ in both cases). Mussels were detached from the rock with a spatula, carried to the laboratory, placed in a $1 \mathrm{~mm}$ mesh screen, and carefully rinsed to remove sand, small shell fragments, and other organisms such as interstitial invertebrates or epibiotic algae. The number of mussels per sample was counted. The biomass of each mussel sample was measured to the nearest gram using spring dynamometers (Pesola ${ }^{\circledR}, 100 \mathrm{~g}$ capacity). Sample volume was estimated by water displacement using a graduated beaker ( $250 \mathrm{ml}$ volume, $2 \mathrm{ml}$ precision). Two-way mixed model ANOVA (Zar 1984) was used to test for differences in the abundance, biomass, and volume of mussels between samples taken at different places (i.e. hummocks, adjacent to hummocks, $30 \mathrm{~cm}$ away from hummocks; fixed factor) and dates (random factor). In this and subsequent ANOVAs, the assumptions of normality and homoscedasticity were respectively evaluated with Shapiro-Wilk and Levene's tests (Zar 1984, Underwood 1997).
Mussels in the samples taken on 8 December 2011 were measured along their antero-posterior axis using Vernier calipers (1 mm precision). Differences in mussel size-frequency distributions between hummocks and single-layered areas (adjacent to hummocks and $30 \mathrm{~cm}$ away from them) were evaluated by means of the Kolmogorov-Smirnov tests (Zar $1984 ; \mathrm{n}=551,405$, and 386, respectively).

\section{Thresholds for hummock formation}

Data from samples taken on 8 December 2011 and 30 April 2012 were pooled to identify possible thresholds in mussel abundance, biomass, and volume per area unit at which hummocks develop. The relationship between the occurrence of hummocking (response variable) and the abundance, biomass, and volume of mussels per area unit was evaluated using binomial logistic regression (Long 1997). McFadden's pseudo- $\mathrm{R}^{2}$ values (calculated as 1 minus the ratio of the log likelihoods of the logistic and the intercept model; Long 1997) were used as a measure of the amount of variability explained by the logistic models. The likelihood ratio test (Long 1997) was used to statistically compare the fit of the logistic model with that of the null, intercept model. Thresholds for hummock formation were estimated as the abundance, biomass, and volume of mussels per area unit at which the logistic curve crosses the $50 \%$ ordinate in the models (i.e. the abundance, biomass, and volume per area unit at which half of the samples are predicted to occur as hummocks; see Bergman et al. 2004, Bütler et al. 2004).

\section{Mussel attachment strength}

The force necessary for the detachment of mussels occurring in hummocks and the single-layered matrix was compared both in quartzite substrate at Punta Cantera and limestone platforms at El Espigón. Force was measured using spring dynamometers equipped with a drag pointer to record maximum force (see Witman \& Suchanek 1984). Two kinds of measurement were taken at each study site:

(1) Force applied to individual mussels. Mussels in single-layered areas and the top of hummocks $(\mathrm{n}=$ 18) were attached to a spring dynamometer (Pesola ${ }^{\circledR}$; $1000 \mathrm{~g}$ capacity) by means of a binder clip. Force was applied perpendicular to the substrate until the mussel was dislodged. All mussels analyzed were within the same size range (15-19 $\mathrm{mm}$ length) to avoid 
potentially confounding influences of size on mussel attachment strength (see Hunt \& Scheibling 2001). We considered mussels that were relatively distant from each other $(50 \mathrm{~cm}$ or more; only 1 mussel per hummock) to ensure that measurements were not affected by the previous pulling of neighboring individuals. We excluded from this analysis those cases where a second individual was removed together with the one attached to the dynamometer (they usually comprised less than $5 \%$ of all measurements; authors' pers. obs.). Measurements were carried out on 30 November 2010 (El Espigón) and 03 December 2010 (Punta Cantera).

(2) Force applied to mussel patches. Epoxy mastic (Poxilina ${ }^{\circledR}$ ) was molded to form $3 \times 3 \mathrm{~cm}$ squares that were cemented on top of hummocks and single-layered mussel patches $(n=10)$. Wire hooks were inserted at the top of the mastic squares before they hardened. A spring dynamometer (Pesola ${ }^{\circledR} ; 5000 \mathrm{~g}$ capacity) was attached to wire hooks once mastic squares hardened (10 min). Force was applied perpendicular to the substrate until the mussel patch fastened to the mastic squares was dislodged. Measurements were carried out on 30 November 2010 (El Espigón) and 21 March 2013 (Punta Cantera).

In both cases, differences in attachment strength between hummocks and the single-layered matrix were separately evaluated for each site/date by means of $t$-tests (Zar 1984).

Additionally, attachment strength was compared between individuals occurring at the top of hummocks (i.e. primarily attached to conspecifics), those occurring at their bottom (i.e. primarily attached to the rock substrate), and mussels from the single-layered matrix. Measurements were made at Punta Cantera on 6 August 2014 following the methods explained above (see 'Force applied to individual mussels'). Mussels at the bottom of hummocks were accessed after gently removing the individuals on top with the aid of forceps and multipurpose scissors (used to cut byssal threads). Differences in attachment strength between mussels occurring at these 3 positions were evaluated with 1-way ANOVA (Zar 1984).

\section{Wave impact on hummocks and the single-layered matrix}

Mussel dislodgment by waves and the formation of bare rock patches were compared between hummocks and single-layered areas of the mussel bed after the passage of cold fronts (i.e. transition zones from warm air to cold air). Cold fronts at the study area occur all year round and generally displace in a SW to NE direction and are followed by precipitation, noticeable drops in temperature, and moderate to strong winds from the SW or S (Celemín 1985). These wind conditions can persist for 12 to $24 \mathrm{~h}$ (Celemín 1985) causing tidal levels well in excess of astronomic predictions (i.e. positive storm surges) and strong wave action (Fiore et al. 2009). Hummocks and similarly sized areas of the single-layered matrix were circled with yellow epoxy paint $(8 \mathrm{~cm}$ diameter circles) 1 or $2 \mathrm{~d}$ before the passage of a cold front on 4 dates in 2011: 13 June $(\mathrm{n}=19), 29$ June $(\mathrm{n}=10)$, 11 August ( $\mathrm{n}=14)$, and 21 August $(\mathrm{n}=13)$. Moreover, 5 mussels at each of these single-layered areas and at the top of these hummocks were marked with a dot of epoxy paint on 1 shell. The occurrence of mussel dislodgment was checked soon after wind and wave conditions calmed down (17 June, 02 July, 15 August, and 23 August, respectively). Wave impacts on circled hummocks and single-layered areas were classified as follows:

(1) Large: 1 or more marked mussels were dislodged and the rock surface became exposed.

(2) Small: 1 or more marked mussels were dislodged but the rock surface remained totally covered by mussels.

(3) Not detectable: The rock surface remained fully covered by mussels and no marked mussel was dislodged.

Chi-squared tests (Zar 1984) were used to evaluate whether the frequency of large, small, and undetectable impacts of wave action differed between hummocks and single-layered areas of the mussel bed.

\section{Temporal sequence of hummock formation and removal by waves}

On 13 June 2011, 19 mussel hummocks and the same number of similarly sized, single-layered areas were circled with epoxy paint (see above). These areas were then surveyed on a weekly basis from 19 June to 02 July and from 11 August to 02 September 2011, and status was classified as hummocked or single-layered irrespective of whether mussel coverage was full or partial. Sequences in the status of circled mussel bed areas were modeled with Markov chains (Bakeman \& Gottman 1997). Markov chains quantify the dependence of a state on preceding states and have a variety of applications in ecological research (see Wootton 2004, Dans et al. 2012, and examples therein). Only the dependence between 2 consecutive states was evaluated here (i.e. a first- 
order Markov chain). Transition probabilities (i.e. the probability of occurrence of a particular state given the occurrence of a previous state) were combined into a stochastic matrix model where rows and columns respectively correspond to previous and current states (i.e. a $2 \times 2$ matrix in this analysis). The probability of observing a specific status at a specific time was obtained from the left eigenvector $(\mathbf{w})$ of the matrix. Each component $\left(\mathbf{w}_{i}\right)$ of this row vector represents here the proportion of time that a circled mussel bed area occurred in each particular coverage status. Poptools 3.2 (i.e. a Microsoft Excel add-in for the analysis of matrix population models and simulation of stochastic processes; Hood 2010) was used to calculate $\mathbf{w}$.

\section{RESULTS}

\section{Characterization of mussel hummocks}

Mussel density, biomass, and volume were significantly higher in hummocks than in single-layered areas (either adjacent to hummocks or $30 \mathrm{~cm}$ apart from them) on both sampling dates (Table 2, Fig. 1). Mussel size-frequency distributions did not significantly differ between hummocks, single-layered areas adjacent to hummocks, and single-layered areas located $30 \mathrm{~cm}$ apart from them (Hummocks vs. Adja-

Table 2. Summary of 2-way mixed model ANOVA comparing abundance, biomass, and volume of Brachidontes rodriguezii mussels in samples $(5 \times 5 \mathrm{~cm}$ squares $)$ taken at different positions within the mussel bed (hummocks, single-layered areas immediately adjacent to hummocks, and single-layered areas $30 \mathrm{~cm}$ away from them; fixed factor) and 2 different sampling dates (8 December 2011 and

30 April 2012; random factor). ${ }^{*} \mathrm{p}<0.05,{ }^{* *} \mathrm{p}<0.01$

\begin{tabular}{|c|c|c|c|}
\hline Source of variation & $\mathrm{df}$ & MS & $F$ \\
\hline \multicolumn{4}{|l|}{ Abundance } \\
\hline Position & 2 & 2041.07 & $395.05^{* *}$ \\
\hline Date & 1 & 942.88 & $182.49^{* *}$ \\
\hline Position $\times$ Date & 2 & 5.17 & 0.03 \\
\hline Error & 36 & 177.10 & \\
\hline \multicolumn{4}{|l|}{ Biomass } \\
\hline Position & 2 & 1227.88 & $305.15^{* *}$ \\
\hline Date & 1 & 282.88 & $70.30^{*}$ \\
\hline Position $\times$ Date & 2 & 4.02 & 0.06 \\
\hline Error & 36 & 66.49 & \\
\hline \multicolumn{4}{|l|}{ Volume } \\
\hline Position & 2 & 412.28 & $88.35^{*}$ \\
\hline Date & 1 & 46.09 & 9.88 \\
\hline Position $\times$ Date & 2 & 4.67 & 0.35 \\
\hline Error & 36 & 13.14 & \\
\hline
\end{tabular}
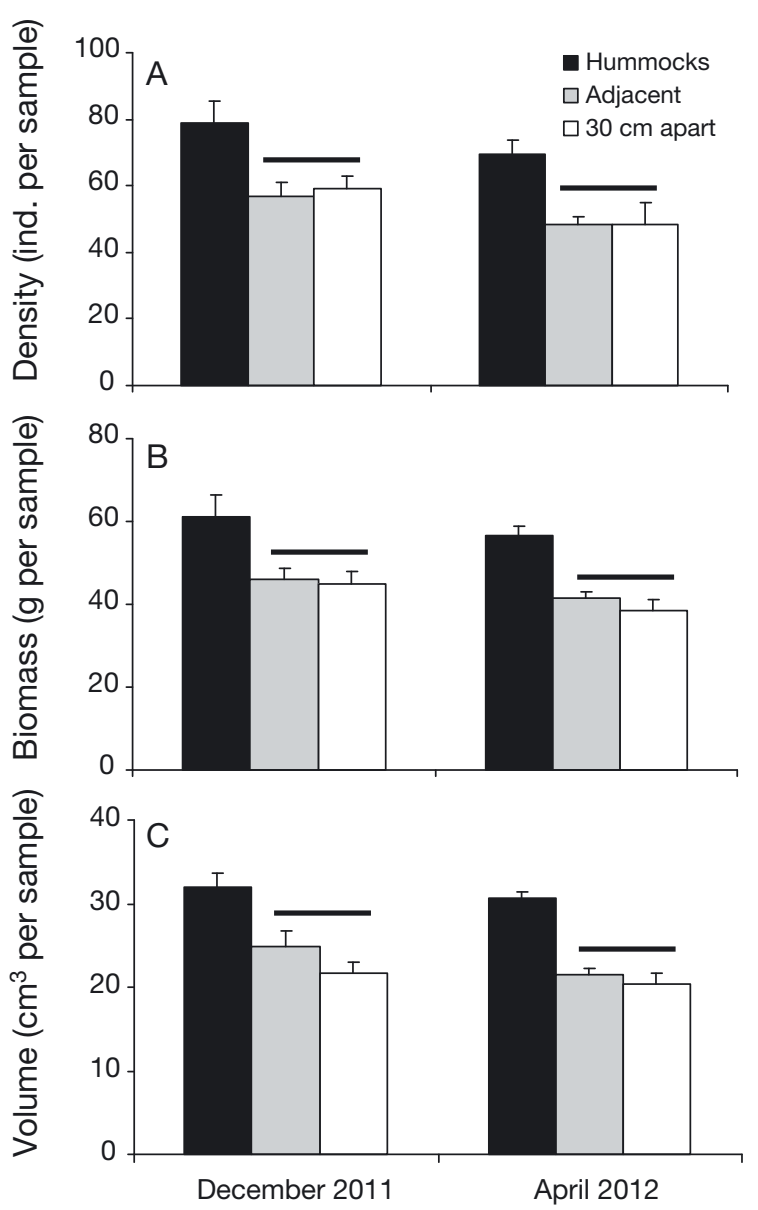

Fig. 1. Mean (SE) (A) density, (B) biomass, and (C) volume of Brachidontes rodriguezii mussels in samples $(5 \times 5 \mathrm{~cm}$ squares) taken at different positions within the mussel bed (hummocks, single-layered areas immediately adjacent to hummocks, and single-layered areas $30 \mathrm{~cm}$ away from them; fixed factor) and 2 different sampling dates (8 December 2011 and 30 April 2012; random factor). The horizontal lines above bars group means that are not significantly different ( $p>0.05$ after 2-way mixed model ANOVA followed by Tukey test)

cent: $D_{\max }=0.044 ;$ Hummocks vs. $30 \mathrm{~cm}$ apart: $D_{\max }=$ 0.049 ; Adjacent vs. $30 \mathrm{~cm}$ apart: $D_{\max }=0.025 ; D_{\max }$ : maximum vertical deviation between the cumulative frequency distribution of 2 samples; $p>0.05$ after Kolmogorov-Smirnov tests in all cases; Fig. 2).

\section{Thresholds for hummock formation}

The relationship between the occurrence (or not) of hummocking (response variable), and the abundance, biomass, and volume of mussels per area unit was best described by binomial logistic regression models than by the null, intercept model $(\mathrm{p}<0.05$ in 


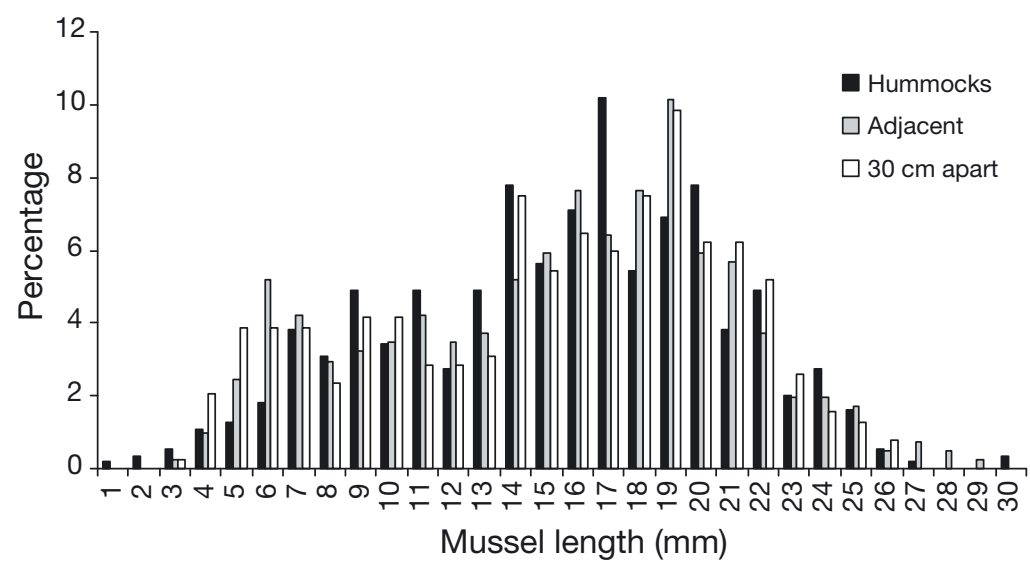

Fig. 2. Size frequency distributions of Brachidontes rodriguezii mussels in samples taken from hummocks, single-layered areas immediately adjacent to hummocks, and single-layered areas $30 \mathrm{~cm}$ away from them. Differences between these distributions are not statistically significant $(p>0.05$ after Kolmogorov-Smirnov tests)

likelihood ratio tests; Table 3). Threshold values of mussel abundance, biomass, and volume per area unit at which hummocks develop (i.e. the abscissa values at which the logistic curve crosses the $50 \%$ ordinate in the regression models) were 228 ind. $\mathrm{dm}^{-2}, 172 \mathrm{~g} \mathrm{dm}^{-2}$, and $93 \mathrm{~cm}^{3} \mathrm{dm}^{-2}$, respectively.

\section{Mussel attachment strength}

Mussels in the top surface of hummocks showed significantly lower attachment strength than those in the single-layered matrix both at Punta Cantera (March 2013) and El Espigón (November 2010) and irrespective of whether force was applied to individuals (Punta Cantera: $t=-3.02$; El Espigón: $t=-3.25$;

Table 3. Estimated parameters, maximum likelihood $(L)$, McFadden's pseudo- $R^{2}$ (i.e. a measure of the amount of variation explained by the logistic models), and observed chisquared values of the likelihood ratio test $(\mathrm{df}=1)$ for binomial logistic regression models relating the occurrence of hummocking with Brachidontes rodriguezii mussel density as well as biomass and volume per area unit. Significant likelihood ratio tests indicate that relationships are best described by binomial regression models rather than by the null intercept model. ${ }^{*} \mathrm{p}<0.01$

\begin{tabular}{|lcrrc|}
\hline $\begin{array}{l}\text { Independent } \\
\text { variable }\end{array}$ & $\begin{array}{c}\text { Parameters } \\
(a, b)\end{array}$ & $L$ & $\begin{array}{c}\text { Pseudo- } \\
\mathrm{R}^{2}\end{array}$ & $\chi^{2}$ \\
\hline Density & $-8.08,0.12$ & 17.85 & 0.33 & $17.76^{*}$ \\
Biomass & $-15.36,0.29$ & 13.27 & 0.50 & $26.93^{*}$ \\
Volume & $-25.57,0.90$ & 9.11 & 0.66 & $35.25^{*}$ \\
\hline
\end{tabular}

$\mathrm{df}=34$ and $\mathrm{p}<0.01$ in both cases; Fig. 3A) or mussel patches (Punta Cantera: $t=-8.15 ;$ El Espigón: $t=-5.86 ; \mathrm{df}=$ 18 and $p<0.01$ in both cases; Fig. 3B).

The individuals occurring at the bottom of hummocks showed higher attachment strength than those at their tops and did not differ in this regard from mussels in single-layered areas (1-way ANOVA: $F=10.08, \mathrm{df}=2,30$, $\mathrm{MS}=10.63,1.05, \mathrm{p}<0.01 ;$ Fig. 4)

\section{Wave impacts on hummocks and the single-layered matrix}

The frequency of mussel dislodgment by waves significantly differed between hummocks and single-layered areas after the 4 measurement periods (Table 4). In all cases, detectable wave impacts (either large or small) were more frequent in hummocks than in the single-layered matrix (Table 4). Mussel dislodgment was observed in just 1 out of 56 marked portions of the single-layered bed (i.e. 1.8\%) analyzed during the 4 measurement periods. In con-

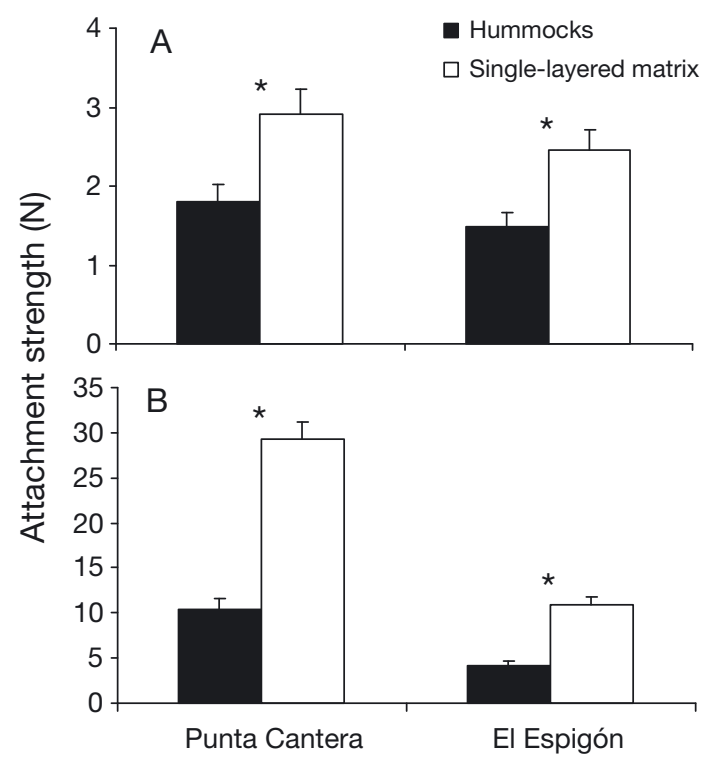

Fig. 3. Mean (SE) attachment strength of Brachidontes rodriguezii mussels (measured as the force necessary to cause dislodgment) in hummocks and the single-layered matrix at 2 study sites. Attachment strength of (A) individual mussels ranging from 15 to $19 \mathrm{~mm}$ length and (B) mussel patches $(3 \times 3 \mathrm{~cm}$ squares). Asterisks indicate statistically significant differences between hummocks and singlelayered areas $(\mathrm{p}<0.05$ after $t$-tests) 


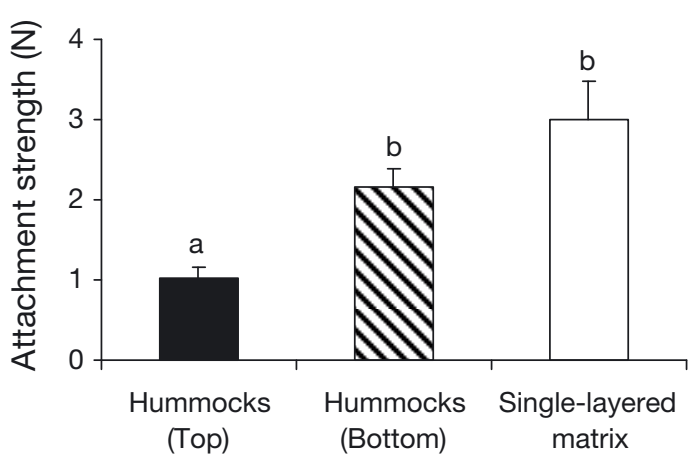

Fig. 4. Mean (SE) attachment strength of individual Brachidontes rodriguezii mussels (measured as the force necessary to cause dislodgment) occurring at the top of hummocks, their bottom, and single-layered areas. Different letters above bars indicate statistically significant differences $(p<$ 0.05 after 1-way ANOVA followed by Tukey tests)

trast, 23 out of 56 hummocks analyzed during the 4 measurement periods (i.e. $41.1 \%$ ) showed evidence of either large (9) or small (14) wave impacts (Table 4).

\section{Temporal sequence of hummock formation and removal by waves}

Hummocked and single-layered mussel bed areas respectively had 71 and $95 \%$ probability to remain the same after weekly sampling intervals. This implies that hummocked areas changed to singlelayered ones at a frequency higher than that of the reverse process (i.e. 29 vs. $5 \%$ of cases). The probabilities of observing hummocked and single-layered areas at a specific sampling unit and time during the course of this survey were 15.4 and $84.6 \%$, respectively. Only 2 out of the 19 hummocks initially marked persisted as such at the end of the monitoring period. Hummocks rarely returned to their original status after their conversion to single-layered

Table 4. Results of chi-squared tests $(\mathrm{df}=2)$ comparing the frequency of large (L), small (S), or not detectable (ND) wave impacts (and concomitant mussel dislodgment; see 'Materials and methods' for definitions) on hummocks and single-layered areas of the mussel Brachidontes rodriguezii bed. ${ }^{*} \mathrm{p}<0.05$, ${ }^{* *} \mathrm{p}<0.01$

\begin{tabular}{|lcccccccc|}
\hline \multirow{2}{*}{$\begin{array}{l}\text { Measurement } \\
\text { period (2011) }\end{array}$} & $\mathrm{n}$ & \multicolumn{4}{c}{ Hummocks } & \multicolumn{4}{c|}{ Single-layered } & \multirow{2}{*}{$\chi^{2}$} \\
& & $\mathrm{~L}$ & $\mathrm{~S}$ & $\mathrm{ND}$ & $\mathrm{L}$ & $\mathrm{S}$ & $\mathrm{ND}$ & \\
\hline 13-17 June & 19 & 8 & 2 & 9 & 0 & 0 & 19 & $21.11^{* *}$ \\
29 June-2 July & 10 & 0 & 4 & 6 & 0 & 0 & 10 & $6.53^{*}$ \\
11-15 August & 14 & 0 & 5 & 9 & 1 & 0 & 13 & $16.66^{* *}$ \\
21-23 August & 13 & 1 & 3 & 9 & 0 & 0 & 13 & $7.89^{*}$ \\
\hline
\end{tabular}

areas (only 8 out of 232 weekly transitions observed during the study period).

\section{DISCUSSION}

Waves often cause substantial mussel dislodgment and patchiness in rocky intertidal environments (e.g. Dayton 1971, Harger \& Landenberger 1971, Paine \& Levin 1981). Mussel dislodgment by waves varies in time (e.g. due to seasonal differences in storm frequency and attachment strength; Hunt \& Scheibling 2001, Carrington 2002b, Carrington et al. 2009), across rocky shore locations (e.g. McQuaid \& Lindsay 2000, O'Connor 2010), across microhabitats within a rocky shore (e.g. higher vs. lower elevations, emerging rock vs. tidal pools, sand-inundated vs. non-inundated areas; Hunt \& Scheibling 2002, Zardi et al. 2006, 2008), and across positions within a patch (e.g. patch center vs. edge; Schneider et al. 2005). In this study, we illustrate that wave dislodgment can also vary due to patchiness in mussel crowding. Multilayered mussel hummocks - characterized by a higher abundance, biomass, and volume of mussels per area unit relative to single-layered areas - show a higher incidence of mussel dislodgment by waves than nearby single-layered areas of the mussel bed. This clearly resembles previous findings in barnacles (when densely packed, barnacles grow more elongated than usual thus also forming hummocks that show increased susceptibility to dislodgment by waves; see Barnes \& Powell 1950, Bertness 1989).

The wave conditions causing the dislodgment of mussels from hummocks are recurrent enough to maintain the mussel bed under study as primarily single-layered. Our results indicate that wave action associated with the periodic passage of cold fronts (mean recurrence time of $7 \mathrm{~d}$ based on historical weather data; Celemín 1985) caused detectable mussel dislodgment in more than $40 \%$ of the hummocks under study. In agreement, only 2 out of the 19 hummocks marked on 13 June 2011 persisted as such after $80 \mathrm{~d}$. Since wave conditions associated with cold fronts rapidly turn hummocks into a single layer of individuals often interspersed by exposed rock, crowding levels above the threshold at which hummocks develop (ca. 230 ind. $\mathrm{dm}^{-2}$ or $90 \mathrm{~cm}^{3} \mathrm{dm}^{-2}$ based on the $50 \%$ ordinate in logistic regression models) are unsustainable with regard to wave impacts. In addi- 
tion, the probability of hummock formation is lower than the probability of hummock conversion into single-layered areas, which helps explain the predominance of single-layered areas in horizontal or nearly horizontal rock surfaces as well as the low density and small sizes of the hummocks themselves.

Increased mussel dislodgment in hummocks relative to single-layered areas can be at least partly explained by decreased attachment strength in mussels occurring at the top of hummocks. Here we observed lower attachment strength in these mussels relative to those in single-layered areas at 2 sites that differ in substrate type (quartzite vs. limestone), and irrespective of whether force was applied to a single mussel (individual removal) or a group of them (patch removal). This is likely because mussels on top of hummocks are primarily attached to conspecifics. Mussel attachment to conspecifics is usually weaker than their attachment to rock (see Harger \& Landenberger 1971). In agreement, our data indicate that individuals occurring at the top of hummocks and primarily attaching to conspecifics show lower attachment strength than those that are primarily attached to rock either at the bottom of hummocks or in single-layered areas. Weaker mussel attachment to conspecifics relative to rock implies that wave action converts hummocks into single-layered areas by selectively dislodging the individuals occurring at their tops. It also suggests that attachment between neighboring conspecifics would not substantially enhance attachment strength at the aggregation level (i.e. whole hummocks).

In addition to differences in mussel attachment strength, hydrodynamic factors are likely to further contribute to increased mussel dislodgment in hummocks relative to single-layered areas. Individual mussels in single-layered areas are protected by neighbors from the forces acting in the direction of flow (drag and acceleration reaction) and primarily exposed to lift forces that act perpendicular to the substrate (i.e. forces resulting from the development of a pressure differential between the top and bottom of each mussel as flow skims over the top of the mussel layer; see Denny 1987, Carrington 2002a). Mussels in hummocks, in contrast, project to flow and are thus likely to experience a combination of drag and lift forces (Carrington 2002a). This suggests that mussels in hummocks undergo a higher exposure to hydrodynamic forces than those in single-layered areas.

Self-thinning relationships - and, thus, limits to crowding - have been described for mussels (e.g. Hughes \& Griffiths 1988, Guiñez \& Castilla 1999) as well as other sessile intertidal invertebrates (e.g. barnacles: Hogarth 1985, Hughes \& Griffiths 1988; ascidians: Guiñez \& Castilla 2001) and have been generally attributed to density-dependent mortality via intraspecific competition. While there certainly is evidence of intraspecific competition in sessile rocky shore invertebrates (e.g. Bertness 1989, Jenkins et al. 2008), actual mechanisms leading to conspecificinduced mortality or removal of densely-packed individuals have remained conjectural in most cases (e.g. self-thinning in barnacles as a possible consequence of individuals being 'overgrown or physically forced off from the rock by expansion of their conspecific neighbors'; Hogarth 1985, p. 215). Our results suggest a crowding-dependent mechanism of mussel removal where increasing occupation of the primary rock substrate leads to mussel hummocking which, in turn, facilitates individual dislodgment by waves. Although this mechanism meets the criteria of intraspecific competition for space (i.e. there is space depletion as densities mount, and a resulting increase in the mortality or removal of individuals), mussel dislodgment here does not solely result from increased inter-individual interference as space becomes limiting. Space depletion alone may limit crowding in cases where direct interference between individuals leads to removal (e.g. barnacle dislodgment due to expansion of adjacent conspecifics; see Hogarth 1985 above) or mortality (e.g. shell crushing due to lateral pressure in densely aggregated mussels; Bertness \& Grosholz 1985). Here, space depletion and direct inter-individual interference could be claimed to account for hummock formation, but the proximal cause of mussel dislodgment is wave action (i.e. a third abiotic party sensu Jones \& Callaway 2007). Clearly, this also applies to examples of hummocking and increased dislodgment by waves in densely packed barnacles (see Barnes \& Powell 1950, Bertness 1989).

Differentiating between mechanisms leading to removal or mortality in gregarious sessile invertebrates (e.g. direct interference between individuals vs. the interaction of inter-individual interference with a third abiotic party; see above) is also important to predict whether upper limits to crowding in a particular species can be context-dependent. For instance, upper limits to crowding maintained by direct interference between individuals alone are expected to be fixed or nearly fixed to a given degree of space occupation (e.g. a given cover or volume of individuals per area unit) irrespective of any environmental variations. In contrast, crowding thresholds resulting from the interplay between inter-individual 
interference and one or more abiotic factors are expected to vary in space and time depending on the magnitude of the abiotic factor(s) in question.

In the case of our study system, upper limits to mussel crowding can be predicted to increase with decreasing exposure to wave forces. For instance, persistent multilayered Brachidontes rodriguezii patches occur on vertical surfaces of boulders and pier pilings protected from breaking waves (Penchaszadeh 1973, authors' pers. obs.). These patches may well result from infrequent mussel dislodgment by waves and the concomitant expansion and coalescence of hummocks. Of note, such apparent contextdependencies in mussel crowding thresholds would remain obscure if the mussel dislodgment mechanism presented here is simply considered as an equivalent to direct interference between individuals.

This example also suggests a mechanism of population control where the impact of a physical factor on population size depends on population density. While the impacts of physical factors on population parameters were originally assumed to be densityindependent (e.g. Nicholson 1933, Smith 1935), they can vary with population density when the number of 'safe' sites in a system is limiting (i.e. mortality will vary depending on whether population size exceeds the number of individuals that safe sites can host; Andrewartha \& Birch 1954). In our study case, the primary rock substrate and the substrate provided by conspecific shells can respectively be viewed as safe and non-safe mussel attachment sites with regards to wave impacts. Once the primary rock substrate is fully occupied by mussels, subsequent addition and growth of individuals forces some of them to occur on top of conspecifics, where they are quickly dislodged by waves. In this way, wave forces would be adjusting mussel population size to the amount of primary rock substrate (i.e. the amount of safe attachment sites) in the intertidal habitat.

Density-dependent impacts of physical factors on population size due to limited availability of safe sites are recurrently quoted in textbooks (e.g. McArthur 2006, Schowalter 2006) but rarely (if ever) supported by field evidence (see Peterson \& Black 1988, Sale \& Tolimieri 2000). When simulating population dynamics, this kind of population control could simply be treated as a typical case of density-dependent regulation through competition for a limiting resource (i.e. primary rock substrate in our example; see Berryman et al. 2002). Nevertheless, accounting for inherent mechanistic detail (e.g. physical factor magnitude as independent of current population size, physical impact magnitude as dependent on popula- tion size, direct effects on population size instead of feedback effects to rates of birth and death; see Sale \& Tolimieri 2000) could help better predict upper limits to population size in variable environmental settings.

Acknowledgements. We thank Silvana Dans for feedback and literature on the use of Markov chain models and 3 anonymous reviewers for their insightful comments. The research presented here was partly funded by a Consejo Nacional de Investigaciones Científicas y Técnicas (CONICET) grant (PIP 112-200801-00732) to M.G.P. and J.L.G. and by Total Foundation funds to the South American Research Group on Coastal Ecosystems (SARCE). M.B. and L.P.A. were supported by CONICET doctoral fellowships. This is a contribution to the program of GrIETA.

\section{LITERATURE CITED}

Allee WC (1927) Animal aggregations. Q Rev Biol 2:367-398 Andrewartha HG, Birch LC (1954) The distribution and abundance of animals. University of Chicago Press, Chicago, IL

Arribas LP, Bagur M, Klein E, Penchaszadeh PE, Palomo MG (2013) Geographic distribution of two mussel species and associated assemblages along the northern Argentinean coast. Aquat Biol 18:91-103

Bakeman R, Gottman JM (1997) Observing interaction. An introduction to sequential analysis, 2nd edn. Cambridge University Press, Cambridge

> Barnes H, Powell HT (1950) The development, general morphology and subsequent elimination of barnacle populations, Balanus crenatus and B. balanoides, after a heavy initial settlement. J Anim Ecol 19:175-179

Bergman KO, Askling J, Ekberg O, Ignell $\mathrm{H}$, Wahlman $\mathrm{H}$, Milberg P (2004) Landscape effects on butterfly assemblages in an agricultural region. Ecography 27:619-628

Berryman AA, Lima Arce M, Hawkins BA (2002) Population regulation, emergent properties, and a requiem for density dependence. Oikos 99:600-606

Bertness MD (1989) Intraspecific competition and facilitation in a northern acorn barnacle population. Ecology 70 : 257-268

> Bertness MD, Grosholz E (1985) Population dynamics of the ribbed mussel, Geukensia demissa: the costs and benefits of an aggregated distribution. Oecologia 67:192-204

Burke RD (1986) Pheromones and the gregarious settlement of marine invertebrate larvae. Bull Mar Sci 39:323-331

> Bütler R, Angelstam P, Ekelund P, Schlaepfer R (2004) Dead wood threshold values for the three-toed woodpecker presence in boreal and sub-Alpine forest. Biol Conserv 119:305-318

> Carrington E (2002a) The ecomechanics of mussel attachment: from molecules to ecosystems. Integr Comp Biol 42:846-852

> Carrington E (2002b) Seasonal variation in the attachment strength of blue mussels: causes and consequences. Limnol Oceanogr 47:1723-1733

Carrington E, Moeser GM, Dimond J, Mello JJ, Boller ML (2009) Seasonal disturbance to mussel beds: field test of a mechanistic model predicting wave dislodgment. Limnol Oceanogr 54:978-986

Celemín AH (1985) Meteorología práctica. Edición del 
Autor, Mar del Plata SL, Degrati M, Pedraza SN, Crespo EA (2012) Effects of tour boats on dolphin activity examined with sensitivity analysis of Markov chains. Conserv Biol 26:708-716

- Davenport J, Moore PG, Magill SH, Fraser LA (1998) Enhanced condition in dogwhelks, Nucella lapillus (L.) living under mussel hummocks. J Exp Mar Biol Ecol 230: 225-234

> Dayton PK (1971) Competition, disturbance, and community organization: the provision and subsequent utilization of space in a rocky intertidal community. Ecol Monogr 41: 351-389

$>$ Denny MW (1987) Lift as a mechanism of patch initiation in mussel beds. J Exp Mar Biol Ecol 113:231-245

$>$ Fiore MME, D'Onofrio EE, Pousa JL, Schnack EJ, Bértola GR (2009) Storm surges and coastal impacts at Mar del Plata, Argentina. Cont Shelf Res 29:1643-1649

Fréchette M, Lefaivre D (1995) On self-thinning in animals. Oikos 73:425-428

Guiñez R (2005) A review on self-thinning in mussels. Rev Biol Mar Oceanogr 40:1-6

> Guiñez R, Castilla JC (1999) A tridimensional self thinning model for multilayered intertidal mussels. Am Nat 154: 341-357

Guiñez R, Castilla JC (2001) An allometric tridimensional model of self-thinning for a gregarious tunicate. Ecology 82:2331-2341

> Guiñez R, Petraitis PS, Castilla JC (2005) Layering, the effective density of mussels and mass-density boundary curves. Oikos 110:186-190

Harger JRE, Landenberger DE (1971) The effects of storms as a density dependent mortality factor on populations of sea mussels. Veliger 14:195-201

Hogarth PJ (1985) Population density, mean weight, and the nature of the 'thinning line' in Semibalanus balanoides (L.) (Cirripedia Thoracica). Crustaceana 49:215-218

Hood GM (2010) PopTools version 3.2.5. Available at www.poptools.org

Hosomi A (1985) On the persistent trend of constant biomass and the constant total occupation area of the mussel Mytilus galloprovincialis (Lamarck). Jpn J Malacol 44: 33-48

> Hughes RN, Griffiths CL (1988) Self-thinning in barnacles and mussels: the geometry of packing. Am Nat 132: 484-491

$>$ Hunt HL, Scheibling RE (1995) Structure and dynamics of mussel patches in tidepools on a rocky shore in Nova Scotia, Canada. Mar Ecol Prog Ser 124:105-115

Hunt HL, Scheibling RE (2001) Predicting wave dislodgment of mussels: variation in attachment strength with body size, habitat, and season. Mar Ecol Prog Ser 213: 157-164

Hunt HL, Scheibling RE (2002) Movement and wave dislodgment of mussels on a wave-exposed rocky shore. Veliger 45:273-277

> Jaubet ML, Genzano GN (2011) Seasonality and reproductive periods of the hydroid Clytia gracilis in temperate littoral ecosystems. Is asexual reproduction the prime mechanism in maintaining populations? Mar Biol Res 7: 804-811

$>$ Jenkins SR, Murua J, Burrows MT (2008) Temporal changes in the strength of density-dependent mortality and growth in intertidal barnacles. J Anim Ecol 77:573-584

Jones CG, Callaway RM (2007) The third party. J Veg Sci 18 $771-776$
Krause J, Ruxton GD (2002) Living in groups. Oxford University Press, Oxford

Long JS (1997) Regression models for categorical and limited dependent variables. Sage Publications, Thousand Oaks, CA

McArthur JV (2006) Microbial ecology: an evolutionary approach. Academic Press, Burlington, MA

> McQuaid CD, Lindsay TL (2000) Effect of wave exposure on growth and mortality rates of the mussel Perna perna: bottom-up regulation of intertidal populations. Mar Ecol Prog Ser 206:147-154

> Nicastro KR, Zardi GI, McQuaid CD (2008) Movement behaviour and mortality in invasive and indigenous mussels: resilience and resistance strategies at different spatial scales. Mar Ecol Prog Ser 372:119-126

Nicholson AJ (1933) The balance of animal populations. J Anim Ecol 2:131-178

O'Connor N (2010) Shore exposure affects mussel population structure and mediates the effect of epibiotic algae on mussel survival in SW Ireland. Estuar Coast Shelf Sci 87:83-91

Paine RT, Levin SA (1981) Intertidal landscapes: disturbance and the dynamics of pattern. Ecol Monogr 51:145-178

Pawlik JR (1992) Chemical ecology of the settlement of benthic marine invertebrates. Oceanogr Mar Biol Annu Rev 30:273-335

Penchaszadeh PE (1973) Ecología de la comunidad del mejillín (Brachidontes rodriguezii D'Orb.) en el mediolitoral rocoso de Mar del Plata, Argentina: el proceso de recolonización. Physis 32:51-64

Peterson CH, Black R (1988) Density-dependent mortality caused by physical stress interacting with biotic history. Am Nat 131:257-270

Sale PF, Tolimieri N (2000) Density dependence at some time and place? Oecologia 124:166-171

Schneider KR, Wethey DS, Helmuth BST, Hilbish TJ (2005) Implications of movement behavior on mussel dislodgement: exogenous selection in a Mytilus spp. hybrid zone. Mar Biol 146:333-343

Schowalter TD (2006) Insect ecology: an ecosystem approach. Academic Press, London

Seed R (1976) Ecology. In: Bayne BL (ed) Marine mussels: their ecology and physiology. Cambridge University Press, Cambridge, p 13-65

Smith HS (1935) The role of biotic factors in the determination of population densities. J Econ Entomol 28:873-898

Suchanek TH (1986) Mussels and their role in structuring rocky shore communities. In: Moore PG, Seed R (eds) The ecology of rocky coasts. Columbia University Press, New York, NY, p 70-96

> Trovant B, Ruzzante DE, Basso NG, Orensanz JM (2013) Distinctness, phylogenetic relations and biogeography of intertidal mussels (Brachidontes, Mytilidae) from the south-western Atlantic. J Mar Biol Assoc UK 93: $1843-1855$

Underwood AJ (1997) Experiments in ecology: their logical design and interpretation using analysis of variance. Cambridge University Press, Cambridge

- Van de Koppel J, Gascoigne JC, Theraulaz G, Rietkerk M, Mooij WM, Herman PMJ (2008) Experimental evidence for spatial self-organization and its emergent effects in mussel beds. Science 322:739-742

> Westoby M (1984) The self-thinning rule. Adv Ecol Res 14: 167-226

Witman JD, Suchanek TH (1984) Mussels in flow: drag and 
dislodgement by epizoans. Mar Ecol Prog Ser 16:259-268 Wootton JT (2004) Markov chain models predict the consequences of experimental extinctions. Ecol Lett 7:653-660

Zar JH (1984) Biostatistical analysis. Prentice-Hall, Englewood Cliffs, NJ

Zardi GI, Nicastro KR, McQuaid CD, Rius M, Porri F (2006) Hydrodynamic stress and habitat partitioning between

Editorial responsibility: Lisandro Benedetti-Cecchi, Pisa, Italy indigenous (Perna perna) and invasive (Mytilus galloprovincialis) mussels: constraints of an evolutionary strategy. Mar Biol 150:79-88

> Zardi GI, Nicastro KR, McQuaid CD, Erlandsson J (2008) Sand and wave induced mortality in invasive (Mytilus galloprovincialis) and indigenous (Perna perna) mussels. Mar Biol 153:853-858

Submitted: March 28, 2014; Accepted: October 17, 2014 Proofs received from author(s): December 11, 2014 